\title{
Spatio-temporal variability of surface water quality of fresh water resources in Ranchi Urban Agglomeration, India using geospatial techniques
}

\author{
Arvind Chandra Pandey • Amit Kumar
}

Received: 27 August 2013/Accepted: 20 February 2014/Published online: 20 March 2014

(C) The Author(s) 2014. This article is published with open access at Springerlink.com

\begin{abstract}
Study was conducted in Ranchi Urban Agglomeration (RUA) to assess the surface water quality of major rivers and reservoirs during pre- and post-monsoon periods. Study indicated increase in chemical contaminants and decrease in biological contaminants during monsoon periods and a positive correlation with built-up land within the catchment of surface water sources. The remote sensing-based approach indicated Swarnrekha river and tributaries as more encroached by built-up land $\left(0.73 \mathrm{~km}^{2}\right.$ within $50 \mathrm{~m}$ buffer $)$ than Jumar river and its tributaries $\left(0.21 \mathrm{~km}^{2}\right)$. For the proper management of the surface water sources in RUA, government attention and interventions are required to minimize the contamination and safeguard the health of local residents.
\end{abstract}

Keywords Surface water quality - Land use/land cover · Built-up encroachment · Remote sensing · GIS

\section{Introduction}

The urban environment has profound impact over global ecosystem (Nezband and Jurgens 2010). Urban land use and land cover change significantly affect spatial and temporal patterns of runoff, which in turn impacts surface water quality (Wilson and Weng 2010; Arnold and Gibbons 1996). The urban impervious surfaces influence the non-point source pollution and water quality by directly

A. C. Pandey · A. Kumar $(\bowtie)$

Centre for Land Resource Management, Central University of Jharkhand, Brambe, Ranchi 835205, India

e-mail: amit.iirs@gmail.com; amit.kumar@cuj.ac.in

A. C. Pandey

e-mail: arvindchandrap@yahoo.com affecting the amount of runoff to water bodies (Dougherty et al. 2004). The surface water contamination is observed mainly due to the presence of physical substances and biological pathogens that make water unfit for human consumption (Sunday 2003). Various physicochemical parameters such as Hydrogen Ion Concentration $(\mathrm{pH})$, Biological Oxygen Demand (BOD), Dissolved Oxygen (DO), Chemical Oxygen Demand (COD), Total Solids (TS), Total Suspended Solids (TSS), Total Dissolved Solids (TDS), Total Hardness (TH), Acidity, Alkalinity (Alk), Calcium $\left(\mathrm{Ca}^{++}\right)$, Magnesium $\left(\mathrm{Mg}^{++}\right)$, Chloride $\left(\mathrm{Cl}^{-}\right)$, Sulphate $\left(\mathrm{SO}_{4}{ }^{2-}\right)$, Presumptive Total Coliform (PTC) and Confirmed Total Coliform (CTC) have a significant role in determining the potability of drinking water (Shaikh and Mandre 2009). All water resources have been reached to a point of crisis due to unplanned urbanization and industrialization (Singh et al. 2002).

Pollution from both domestic and agricultural sources increases and has contaminated aquatic ecosystems viz., rivers, ponds, lakes, and reservoirs (Asante et al. 2008). The fresh water obtained directly from the major surface water sources viz., reservoirs to satisfy the needs of rapidly growing urban populations are, however, variable in quality due to contamination (DFID 1999). The main sources of water contamination include indiscriminate disposal of domestic, industrial and municipal solid and liquid wastes; improper land use; poor agricultural practices and environmental degradation within the watershed catchment.

Contamination in streams and rivers is influenced by a variety of factors. Point sources of pollutants are of major concern in an urban area; on the other hand, non-point sources are of major concern in the rural areas (Asante et al. 2008). Impermeable surfaces allow pollutants to enter into the streams directly rather than filtering through soils. 
Harmful pollutants from construction, traffic and sediment deposition increase turbidity, reducing the amount of light penetration, retard photosynthesis and hence may lead to decrease in the food supply to the aquatic life (Atasoy et al. 2006). Further, urban discharge also substantially degrades surface water as well as groundwater quality (Mapani 2005; Held et al. 2007). Therefore, it is essential for researchers, planners and decision makers to assess the impact of urbanization on quality and quantity of surface and ground water for its optimal utilization and sustainable environment (Jat et al. 2009). Many researchers have documented the surface and ground water depletion and pollution in India due to explosive growth and uneven distribution of population, poor irrigation practices, rapid urbanization, large-scale deforestation and improper land use practices (Jaiswal et al. 2003).

The rapid built-up growth in and around Ranchi Urban Agglomeration (RUA) appeared haphazard since its formation as state capital in the year 2000 (Kumar et al. 2011a, b). Mushrooming of high rising building and industries within the urban landscape have substantially affected water quality in their vicinity due to inclusion of municipal and industrial wastes in the river and water reservoir. Looking into the high pace of development of RUA, the present study focuses on seasonal physicochemical characteristics of surface water during pre- and post-monsoon periods as well to evaluate the impact on surface water quality due to urban land use/land cover in recent years by employing geospatial technology. The built-up encroachment over river course and seasonal drainage channels were quantified to analyze the impact of built-up development on river environment.

\section{Study area}

The study area $\left(317.6 \mathrm{~km}^{2}\right)$ comprising RUA is situated on Chotanagpur plateau at $645 \mathrm{~m}$ above sea level, and located between $85^{\circ} 13^{\prime}$ to $85^{\circ} 25^{\prime} \mathrm{E}$ longitude and $23^{\circ} 13^{\prime}$ to $23^{\circ} 26^{\prime} \mathrm{N}$ latitude (Fig. 1). Administratively, the area is comprising parts of Kanke, Namkum and Ratu Community Development Blocks in Ranchi district of Jharkhand, India and having a population of $11,19,000$ persons (UNPD 2010). The demarcation of study area was based on $2 \mathrm{~km}$ buffer of Ranchi Municipal Corporation boundary, which covers majority of continuous built-up land of RUA as observed in satellite image of the year 2010. Swarnrekha river and its tributaries viz. Harmu, Potpoto, Kanchi, Saphi, Jumar, Radhu and Tajna are the major rivers draining the area. The river Subarnarekha originates near Hatia reservoir and flow from south-west to north-east direction. The accumulated discharge of river Subarnarekha and its major tributary river Jumar get stored in the Getalsut reservoir. River
Jumar, Potpoto, Harmu and other tributaries of Swarnrekha river flow through the urbanized area of RUA.

\section{Data source and methodology}

The surface water quality in and around RUA was analyzed in a total of eight locations, which were collected during pre-monsoon (Feb. 2007, Feb. 2008, May 2009, Feb. 2010) and post-monsoon (Sept. 2007, Oct. 2008, Oct. 2009) periods from 2007 to 2010. Three locations are on river Subarnarekha, one location is on its major tributary i.e., Jumar river and four locations are on three major reservoirs (Kanke, Hatia and Getalsut reservoir), which are providing drinking water supply to Ranchi and surrounding regions (Fig. 1; Table 1).

Data pertaining to surface water quality were collected from Jharkhand State Pollution Control Boards. The surface water quality parameters viz., $\mathrm{pH}, \mathrm{BOD}, \mathrm{DO}, \mathrm{COD}, \mathrm{TS}, \mathrm{TSS}$, $\mathrm{TH}, \mathrm{TDS}$, Acidity, Alk, $\mathrm{Ca}^{++}, \mathrm{Mg}^{++}, \mathrm{Cl}^{-}, \mathrm{SO}_{4}{ }^{2-}$, PTC, CTC were analyzed to detect variation in water quality parameter during pre-monsoon (Feb. 2007, Feb. 2008, May 2009, Feb. 2010) and post-monsoon (Sept. 2007, Oct. 2008, Oct. 2009) periods from 2007 to 2010 at eight locations. The water quality parameters were analyzed with reference to the prescribed limit given by World Health Organisation and Bureau of Indian Standards (Table 2). The assessment of water quality in the major reservoir and rivers in RUA was also made for pre- and post-monsoon period. It is to remark that the pattern and intensity of rainfall in Ranchi is erratic. The average monsoon rainfall is ca. 1,200 $\mathrm{mm}$ and generally begins in the month of June, reaches to its maximum intensity during JulyAugust and ends by September-October. Apart from monsoon rainfall, the precipitation generally occurs during December-February, which recorded ca. $120 \mathrm{~mm}$.

Multi-resolution satellite data viz., IRS LISS-III (acquired on 15 February 2009) and WorldView-II (acquired on 15 June 2010) were used to map land use/land cover of RUA to relate it with surface water quality in the catchment areas (Fig. 2). The satellite data of IRS LISS-III were classified into five categories viz., built-up, vegetation, water body, agricultural land and others by employing unsupervised ISODATA classification technique. The built-up class includes constructed areas such as residential area, commercial complexes, institutions and slums. All green features viz. forest cover, trees were classified under vegetation class. The land primarily used for agricultural activities was categorized under agricultural land. river, ponds, canals, etc. were identified under water body category. The 'other' class comprised of rock outcrops, barren land, brick kiln area, etc. The accuracy assessment was carried out using 50 sample points generated through random stratified sampling technique. The overall accuracy of the classified image was $83.3 \%$. The kappa coefficient was 0.88 . The 


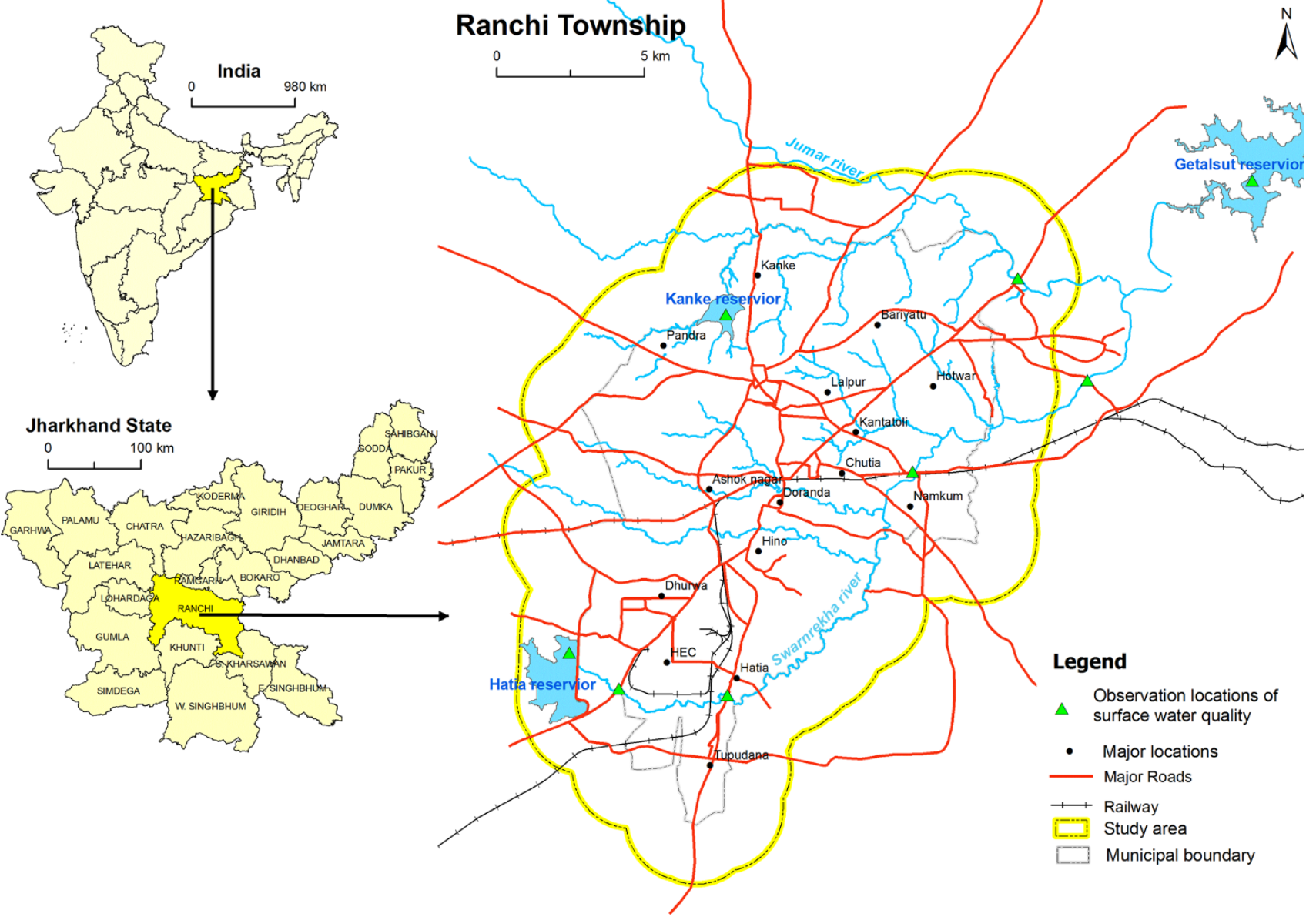

Fig. 1 Location map of study area

Table 1 Sampling locations of water quality parameters in RUA

\begin{tabular}{lll}
\hline S1. No. & Sampling locations & Geographical coordinates \\
\hline 1 & $\begin{array}{l}\text { Swarnrekha river near Hatia } \\
\text { reservoir }\end{array}$ & $23^{\circ} 17^{\prime} 07^{\prime \prime} \mathrm{N}$ and $85^{\circ} 16^{\prime} 01^{\prime \prime} \mathrm{E}$ \\
& Swarnrekha river at Hatia & $23^{\circ} 17^{\prime} 00^{\prime \prime} \mathrm{N}$ and $85^{\circ} 18^{\prime} 32^{\prime \prime} \mathrm{E}$ \\
3 & Swarnrekha river at & $23^{\circ} 21^{\prime} 04^{\prime \prime} \mathrm{N}$ and $85^{\circ} 22^{\prime} 09^{\prime \prime} \mathrm{E}$ \\
& Namkum & \\
4 & Swarnrekha river at & $23^{\circ} 22^{\prime} 50^{\prime \prime} \mathrm{N}$ and $85^{\circ} 25^{\prime} 36^{\prime \prime} \mathrm{E}$ \\
& Tantisilwai & \\
5 & Jumar river at BSNL & $23^{\circ} 24^{\prime} 37^{\prime \prime} \mathrm{N}$ and $85^{\circ} 24^{\prime} 16^{\prime \prime} \mathrm{E}$ \\
6 & Hatia reservoir & $23^{\circ} 17^{\prime} 43^{\prime \prime} \mathrm{N}$ and $85^{\circ} 15^{\prime} 31^{\prime \prime} \mathrm{E}$ \\
7 & Kanke reservoir & $23^{\circ} 24^{\prime} 19^{\prime \prime} \mathrm{N}$ and $85^{\circ} 18^{\prime} 28^{\prime \prime} \mathrm{E}$ \\
8 & Getalsut reservoir & $23^{\circ} 27^{\prime} 15^{\prime \prime} \mathrm{N}$ and $85^{\circ} 33^{\prime} 14^{\prime \prime} \mathrm{E}$ \\
\end{tabular}

wrong identities of pixels were corrected through selective field verification as well as visual interpretation using high resolution WorldView-II satellite data.

The high resolution WorldView-II satellite data were used to map built-up land in the vicinity of major rivers and drainage channels. Digital image processing techniques employing normalized index of Principal Component Analysis-1 and NIR-2 band $(0.860-1.040 \mathrm{~nm})$ were used to extract built-up land (Kumar et al. 2012). The extracted builtup land was used to calculate the built-up encroachment within buffer zones of 25 and $50 \mathrm{~m}$ along the tributaries of Swarnrekha and Jumar rivers within Ranchi urban area. The catchment area was demarcated based on drainage pattern delineated using WorldView-II satellite data. The digital image processing and GIS analysis were carried out using ERDAS Imagine 9.2 and ArcGIS 9.3 software, respectively.

\section{Result and discussion}

The water quality pertaining to 16 parameters was analyzed for the period February, 2007 to May, 2010 in RUA, which exhibits contamination above the prescribed limit and shows variability in concentration during pre- and postmonsoon periods with reference to BOD, TSS, TDS, PTC and CTC. Concentration was found within prescribed limit with reference to $\mathrm{pH}, \mathrm{DO}, \mathrm{COD}, \mathrm{TH}, \mathrm{Ca}^{++}, \mathrm{Mg}^{++}, \mathrm{Cl}^{-}$, Alk, TDS, $\mathrm{SO}_{4}{ }^{2-}$ (Fig. 3a-p; Table 3). 
Table 2 Desirable limits of water quality parameters

\begin{tabular}{|c|c|c|c|}
\hline Sl. No. & Parameters (unit) & $\begin{array}{l}\text { Desirable } \\
\text { limit }\end{array}$ & Reference \\
\hline 1 & Potential of hydrogen, $\mathrm{pH}$ & $6.5-8.5$ & IS: 10500 \\
\hline 2 & Dissolved oxygen, DO (mg/L) & $>5.0$ & IS: 10500 \\
\hline 3 & $\begin{array}{l}\text { Biological oxygen demand, BOD } \\
(\mathrm{mg} / \mathrm{L})\end{array}$ & 2.0 & \\
\hline 4 & $\begin{array}{l}\text { Chemical oxygen demand, COD } \\
(\mathrm{mg} / \mathrm{L})\end{array}$ & 105.0 & IS: 10500 \\
\hline 5 & Magnesium, $\mathrm{Mg}^{++}(\mathrm{mg} / \mathrm{L})$ & 30.0 & IS: 10500 \\
\hline 6 & Acidity & - & \\
\hline 7 & Sulfur, $\mathrm{SO}_{4}(\mathrm{mg} / \mathrm{L})$ & 250.0 & WHO 2008 \\
\hline 8 & Calcium, $\mathrm{Ca}^{++}(\mathrm{mg} / \mathrm{L})$ & 75.0 & IS 10500:1991 \\
\hline 9 & Chloride, $\mathrm{Cl}^{-}(\mathrm{mg} / \mathrm{L})$ & 250.0 & WHO 2008 \\
\hline 10 & Alkaline, Alk (mg/L) & 200.0 & IS 10500:1991 \\
\hline 11 & $\begin{array}{l}\text { Total suspended solids, TSS } \\
(\mathrm{mg} / \mathrm{L})\end{array}$ & 60.0 & \\
\hline 12 & Total hardness, TH (mg/L) & 300.0 & IS 10500:1991 \\
\hline 13 & Total solids, TS (mg/L) & - & \\
\hline 14 & $\begin{array}{l}\text { Total dissolved solids, TDS } \\
(\mathrm{mg} / \mathrm{L})\end{array}$ & 500.0 & $\begin{array}{l}\text { IS: } 10500 \text {, and } \\
\text { WHO } 2008\end{array}$ \\
\hline 15 & $\begin{array}{l}\text { Presumptive total coliform, PTC } \\
\text { (MPN) }\end{array}$ & 500.0 & \\
\hline 16 & $\begin{array}{l}\text { Confirmed total coliform, CTC } \\
\text { (MPN) }\end{array}$ & 500.0 & \\
\hline
\end{tabular}

WHO (2008) Guidelines for drinking-water quality, third edition incorporating, the first and second agenda-volume-1 recommendations

Spatial and temporal variability of surface water quality

The $\mathrm{pH}$ and concentration of DO exhibited significant increase during pre-monsoon and decrease during postmonsoon periods. At majority of the locations, $\mathrm{pH}$ was found within the prescribed limits, whereas the concentration of DO was above the prescribed limit. Although the concentration of COD, TH, $\mathrm{Ca}^{++}, \mathrm{Mg}^{++}, \mathrm{Cl}^{-}, \mathrm{Alk}$, and $\mathrm{SO}_{4}{ }^{2-}$ exhibited variations, it remained within the prescribed limit at all locations (Fig. 3). On the contrary, the concentration of BOD was above the prescribed limit at each locations during certain (specifically pre-monsoon) periods. The BOD concentration was under the prescribed limit at Hatia reservoir during pre-monsoon periods and at Jumar river during post-monsoon period. There is an increase in the concentration of BOD in the reservoirs (Hatia reservoir, Kanke reservoir, Getalsut reservoir) and Jumar river but the decrease in BOD level in river water near industrial locations was also observed at Hatia, Namkum and Tantisilwai. Although the concentration of TS remain within prescribed limit, it showed anomalous high increase between February, 2008-September, 2008 and May, 2009-May, 2010 at all observed locations.

The concentration of TSS and TDS was found generally beyond permissible limit during various observation periods. In $48 \%$ of the observations, TSS was above the prescribed limit and exhibits significant increasing trend at all locations. A decreasing trend in TSS concentration was identified in river water (river Swarnrekha at Hatia, Namkum, Tantisilwai and in Jumar river), whereas an increasing trend was found at majority of reservoirs (Getalsut reservoir, Hatia reservoir and Kanke reservoir) during postmonsoon (Fig. 31). In $25 \%$ of the observations, the TDS was above the prescribed limit at all sample locations during February, 2007-October, 2008 (Fig. 3m). The concentration of PTC was observed above the prescribed limit during the observation at all locations, whereas the concentrations of CTC were under the prescribed limits during majority of the observations (Fig. 3p). It has also been observed that the concentrations of CTC in reservoirs were decreased after monsoon rainfall in the consecutive two observation periods. Increase in TDS during monsoon periods reflects high sediment influx in the reservoir water due to erosion of surface soil generated during rainwater runoff in the catchment areas of various rivers and streams.

The average concentration of various contaminants analyzed during 2007-2010 (Table 3) indicates that the maximum contamination were observed in Swarnrekha river near industrial area (Tantisilwai), where BOD (4.1 mg/L), TDS (68.4 mg/L), and TC (2,175 mg/L) were above the prescribed limits. The BOD (4.1 mg/L), COD (52.9 mg/L), TH (108.8 mg/L), $\mathrm{Ca}^{++}(28.9 \mathrm{mg} / \mathrm{L}), \mathrm{Mg}^{++}$ (10.5 mh/L), $\mathrm{Cl}^{-}(91.0 \mathrm{mg} / \mathrm{L})$, acidity $(24.4 \mathrm{mg} / \mathrm{L}), \mathrm{TS}$ (543.6 mg/L), TDS (475.3 mg/L), $\mathrm{SO}_{4}{ }^{2-}(16.3 \mathrm{mg} / \mathrm{L})$, and CTC (460 MPN) were also present in high concentration at this location. The second maximum polluted location was also in Swarnrekha river at Hatia, where BOD (3.3 mg/L), TSS (73.3 mg/L) and PTC (2,162.5 MPN) were above the prescribed limits followed by reservoirs (Getalsut and Kanke reservoir), where BOD and PTC were above the prescribed limit and $\mathrm{pH}$ (7.2) and alk (72.1 mg/L) were maximum with reference to all other locations. Getalsut reservoir was identified as the least polluted location followed by Hatia reservoir, which was largely affected by PTC (1,500 MPN).

The temporal observations of water quality parameters during 2007-2010 exhibit that the three major parameters PTC, BOD and TDS were above the prescribed limit at various locations in RUA (Table 3), which is due to the influence of septic discharges from the poorly planned sewerage system in RUA.

Pre- and post-monsoon surface water quality assessment

The concentration of majority of parameters decreased during post-monsoon periods except TS, TDS and PTC (Fig. 4a-p; Table 3). This may be due to the inclusion of 


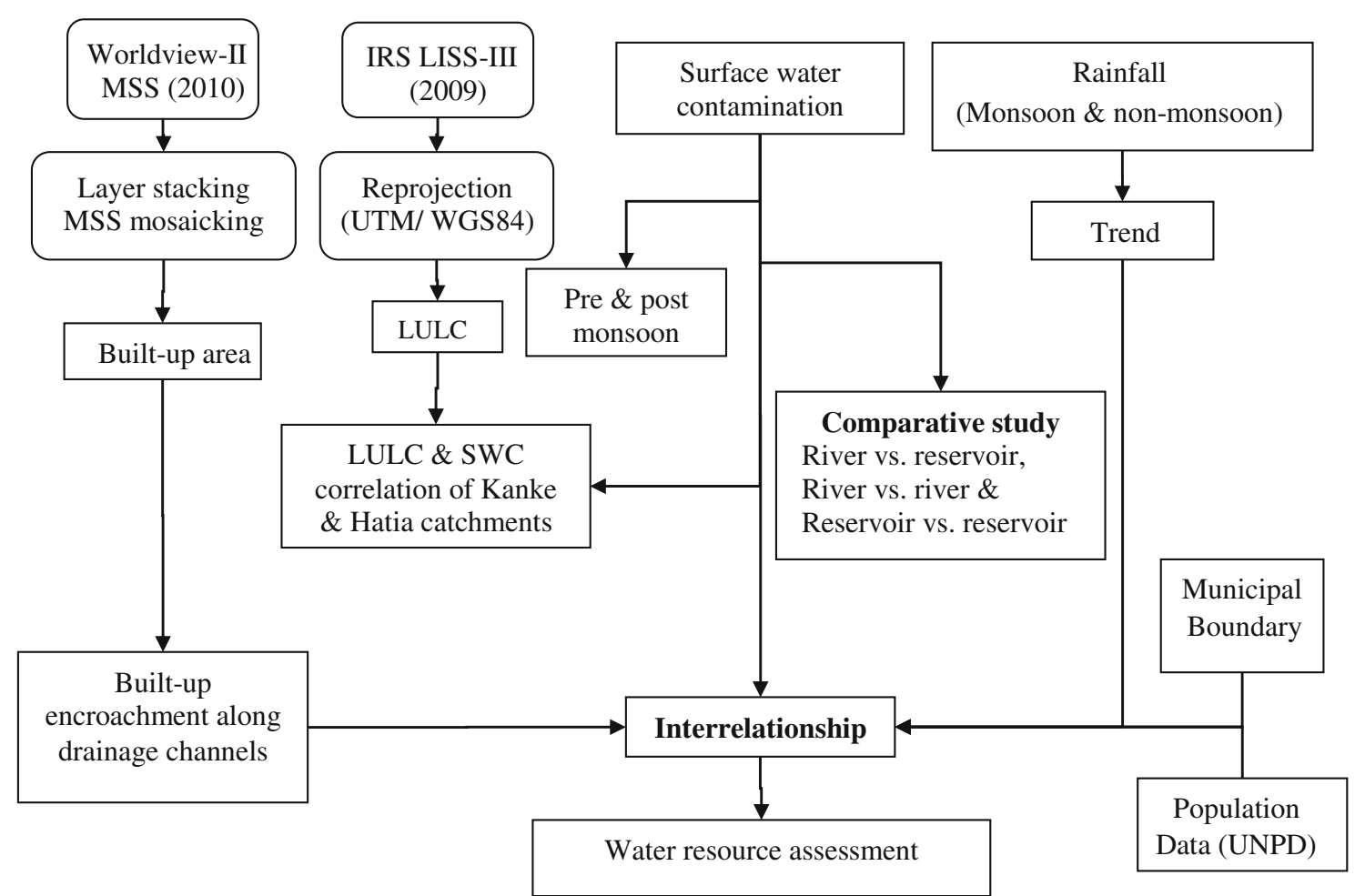

Note: UNPD - United Nations Population Division

SWC - Surface Water Quality

Fig. 2 Methodological flow chart

rainwater, accumulated through runoff within the catchment area, to the river and reservoirs, which reduced the concentration of chemical pollutants, whereas, increased the concentration of TS, TDS and PTC due to high runoff and concomitant erosion in the catchment area.

The water in the Swarnrekha river was found contaminated only in some parts and the maximum contamination was observed near Tantisilwai where TS, TDS and CTC were increased during post-monsoon periods (Fig. 4i-n) followed by Namkum and Hatia. Decrease in concentration of chemical pollutants and increase in concentration of TS, TDS, PTC and CTC in Swarnrekha river were observed in comparison to Jumar river during post-monsoon periods (Fig. 4i-p).

The average surface water quality parameters of rivers and reservoirs were analyzed separately during pre- and post-monsoon periods to ascertain the trend of contaminations (Fig. 5a, b). This exhibits decrease in concentration of majority of pollutants during post-monsoon (except $\mathrm{pH}$ in reservoir and TSS in river), whereas, increase in bacteriological contaminants (except CTC in reservoir) during post-monsoon periods in reservoirs as well as in river water. River water was more contaminated compared to the reservoir water, which may be attributed to discharge of household and industrial waste in the rivers and lack of adequate water to dilute the concentration of contaminants, whereas, in the reservoirs, the concentration of contaminants reduced due to accumulation of sufficient amount of water draining from their catchments. The concentration of TS, TDS and TC in the river water and the reservoir water increases during postmonsoon depending on their catchment area. Among the reservoirs, the Getalsut reservoir was found least contaminated may be because of its largest catchment area as well as large water spread area.

The surface water quality at all the locations (river and reservoirs) in RUA was averaged to evaluate the change in the concentration during pre- and post-monsoon periods (Fig. 5c, d). It was found that the concentration of COD, Acidity, $\mathrm{Ca}^{++}, \mathrm{Cl}^{-}$and Alk was significantly reduced, whereas concentration of TS and TDS was significantly increased during post-monsoon periods. The concentration of remaining parameters exhibit no or slight change during pre- and post-monsoon periods.

Comparative assessment of water quality in Swarnrekha river and Jumar river

The catchment area of Swarnrekha river up to Tantisilwai $\left(289.7 \mathrm{~km}^{2}\right)$ and Jumar river up to BSNL $\left(281.0 \mathrm{~km}^{2}\right)$ 
(a)

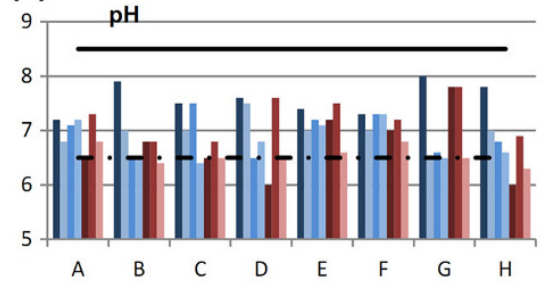

(d)

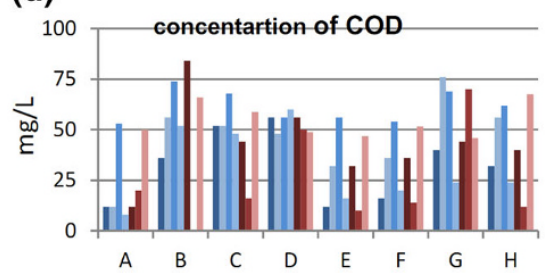

(g)

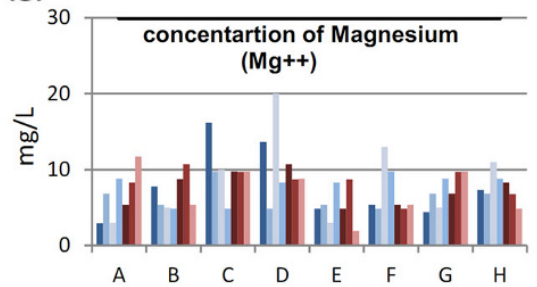

(j)

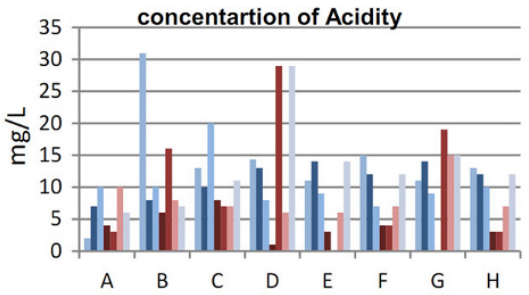

(m)

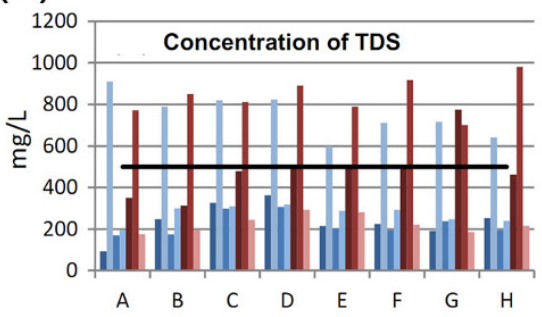

(p)

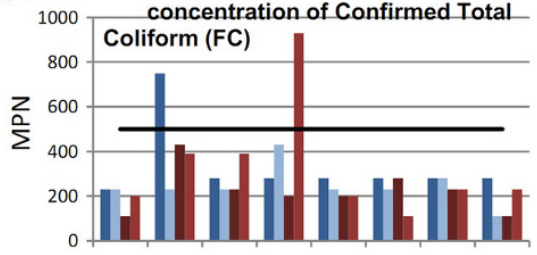

(b)

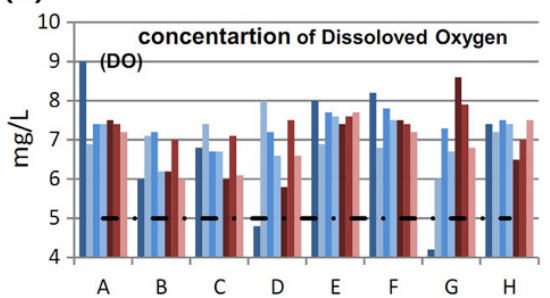

(e)

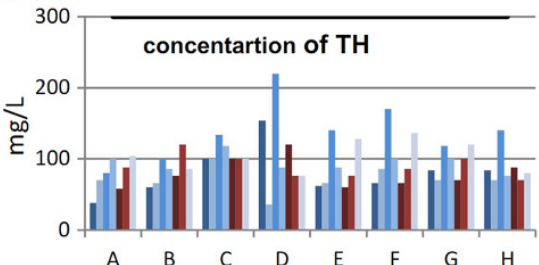

(h)

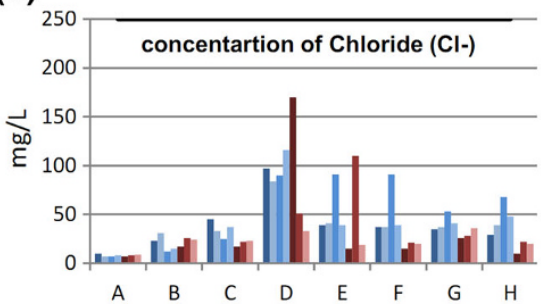

(k)

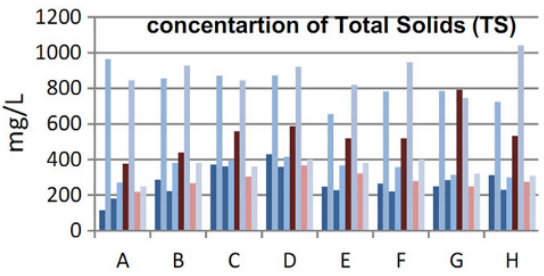

(n)

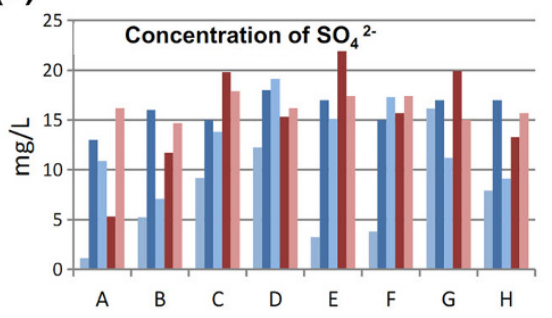

(c)

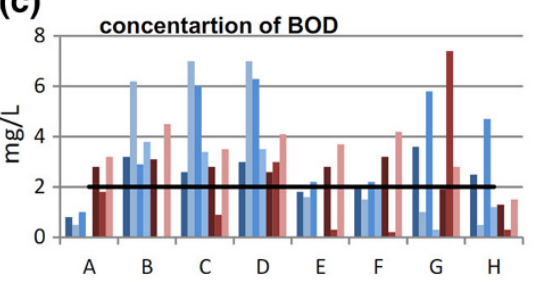

(f)

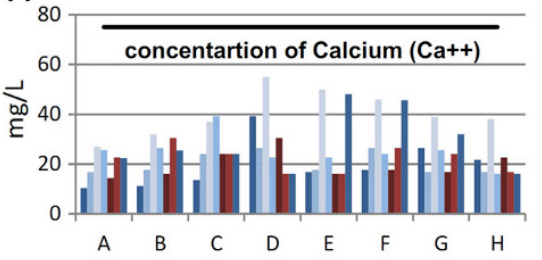

(i)

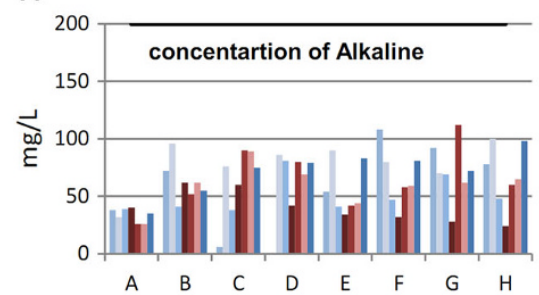

(I)

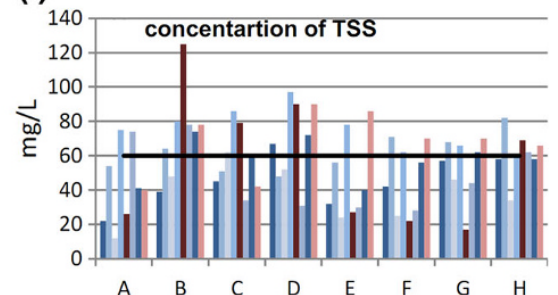

(o)

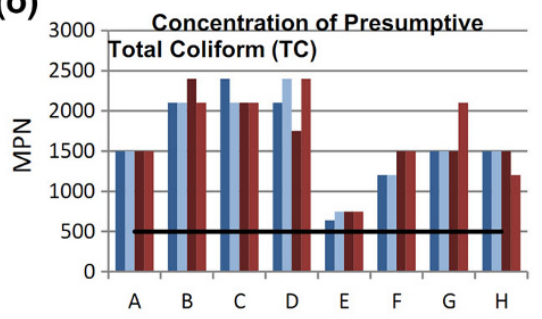

Fig. 3 Pre- and post-monsoon concentration of a Hydrogen ion concentration $(\mathrm{pH}), \mathbf{b}$ dissolved oxygen, $\mathbf{c}$ biological oxygen demand, $\mathbf{d}$ chemical oxygen demand, e total hardness, $\mathbf{f}$ calcium, $\mathbf{g}$ magnesium, $\mathbf{h}$ chloride, $\mathbf{i}$ alkaline, $\mathbf{j}$ acidity, $\mathbf{k}$ total solids, $\mathbf{I}$ total suspended solids, $\mathbf{m}$ total dissolved solids, $\mathbf{n}$ sulphate, o presumptive total coliform, $\mathbf{p}$ confirmed total coliform, in major reservoirs and river flowing through RUA viz: Swarnrekha river at Hatia reservoir $A$, Hatia $B$, Namkum $C$, Tantisilwai $D$, Getalsut reservoir $E$, and Hatia reservoir $F$, Kanke reservoir $G$ and Jumar river at BSNL $H$ 
Table 3 Percent changes in post-monsoon concentration of water quality parameters with reference to pre-monsoon concentration during 2007-2010 (Values are in percent)

\begin{tabular}{|c|c|c|c|c|c|c|c|c|c|c|c|c|c|c|c|c|}
\hline Loc. & $\mathrm{H}$ & O. & OD & OD & + & Icidity & 04 & $a^{++}$ & $\mathrm{Cl}-$ & Alk & TSS & T.H. & T.S. & TDS & PTC & CTC \\
\hline & 4 & -9.8 & 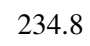 & -3.8 & 57.6 & & r & & & & & & 57.0 & 58 & 0.0 & -32 \\
\hline 1 & 4 & -9.4 & ( & - & 1 & & 1 & & 10.1 & & & 5 & 30.5 & & 7.1 & -16 . \\
\hline $\mathrm{N}$ & .6 & -12 & 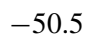 & 46.0 & T. & 10.0 & 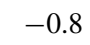 & & 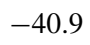 & (5) & - & & 42.4 & 45 & 0.1 & 21. \\
\hline 1 & 5.6 & -5 . & 34.3 & -29.6 & -19.6 & 1.7 & -36.5 & $t$ & - & 14 & -2 & -2 & 5 & 5 & -7.8 & 59. \\
\hline $\mathrm{R}$ & 0.0 & -6.6 & 21.4 & -23.4 & -3.7 & -73.2 & 11.0 & -25.4 & -8.6 & -35.2 & -32.0 & -1.1 & 85.0 & 99.6 & 7.9 & -21 \\
\hline $\mathrm{R}$ & -1.4 & -8.3 & 31.2 & -19.4 & -36.4 & -55.6 & -8.3 & -21.4 & -63.3 & -36.6 & -29.4 & -9.0 & 79.0 & 91.1 & 25.0 & -23 \\
\hline $\mathrm{KR}$ & 5.8 & 20.7 & 52.3 & -23.5 & 40.0 & 0.0 & 0 & 7 & -2 & 6 & 30.9 & 4.0 & 6 & 99.0 & 20.0 & -17 \\
\hline 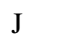 & 8.5 & -11.9 & 53 & -31.3 & -21.2 & -62.6 & 1 & 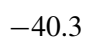 & - & -3 & .7 & -14.3 & 8 & 107.7 & -10.0 & -12 \\
\hline RT & -2.3 & -6.1 & -11.0 & -28.7 & 0.4 & -37.9 & -12.8 & -33.3 & -28.9 & -11.1 & -1.8 & -5.1 & 67.1 & 73.5 & 2.5 & -3 \\
\hline
\end{tabular}

Loc. locations, $H$ Hatia, $S H$ Swarnrekha river at Hatia, $S N$ at Namkum, $S T$ at Tantisilwai, GR Getalsut reservoir, $H R$ Hatia reservoir, KR Kanke reservoir, $J$ Jumar river at BSNL, $R T$ Ranchi township
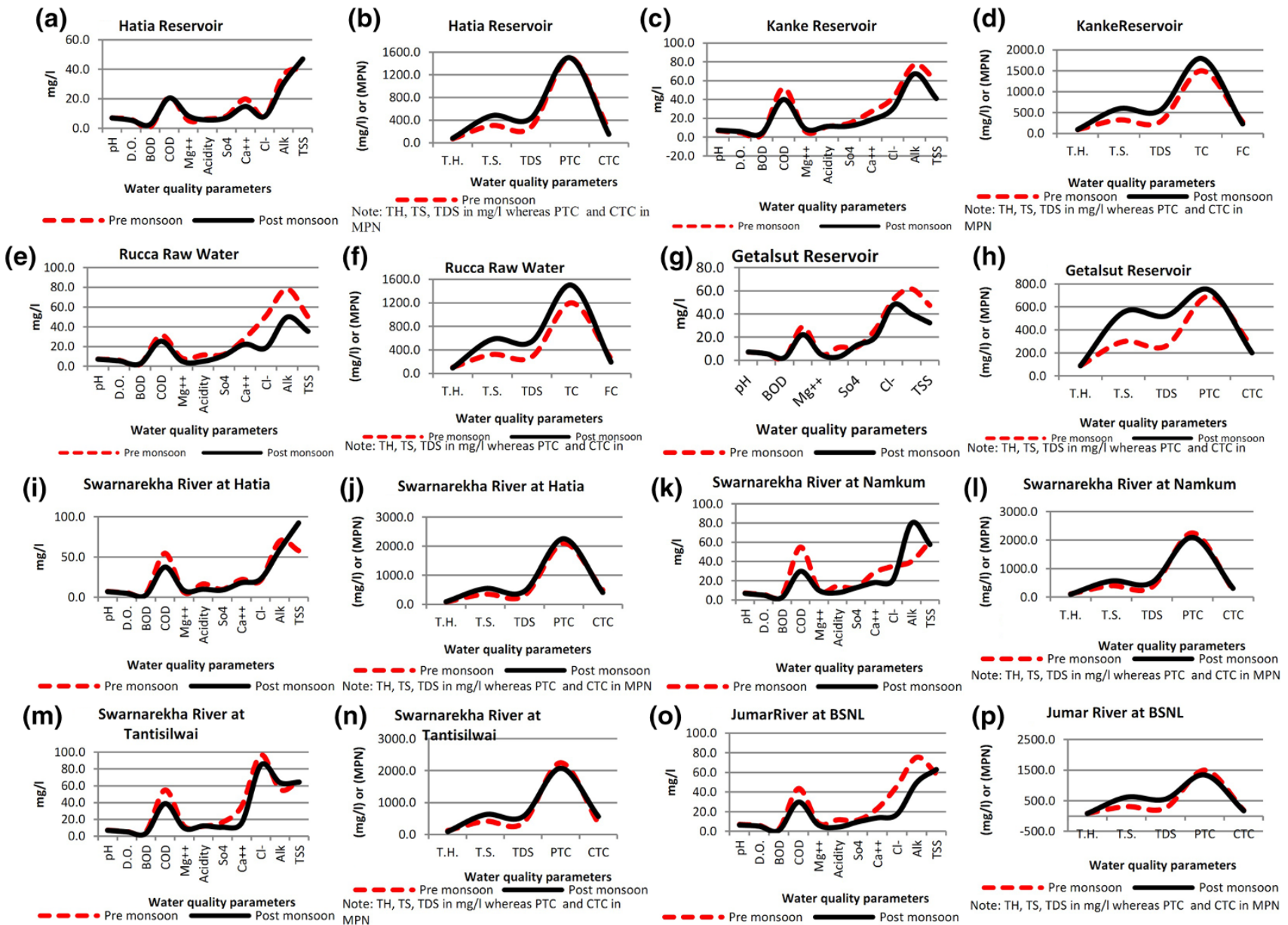

Fig. 4 Water quality status $\mathbf{a}-\mathbf{h}$ in the river water and $\mathbf{i}-\mathbf{p}$ in the reservoirs during pre and post-monsoon periods in 2007-2010

were comparatively analyzed to determine the effect of built-up spread on surface water quality (Figs. 6, 7). The built-up land quantification was made using unsupervised classified satellite imagery of IRS LISS-III acquired in the year 2009 and used in the quantification of built-up coverage within the (upstream) catchment area of said rivers.

Even though the (upstream) catchment area and distance from the source of the river to the observation points are comparable (Table 4), the water quality contamination was 


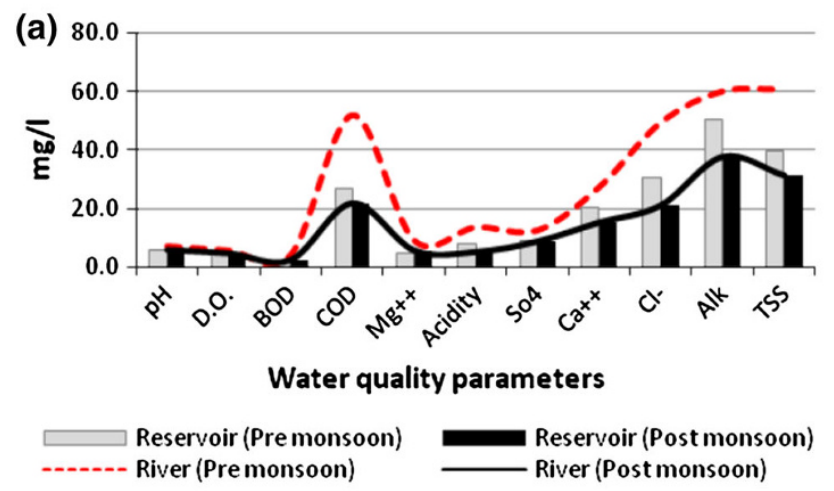

(c)

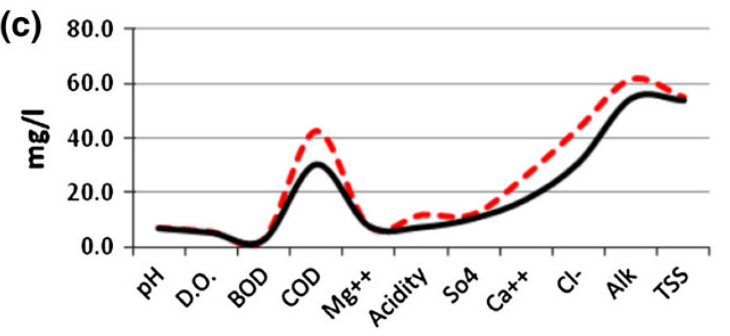

Water quality parameters

------ Premonsoon Post monsoon
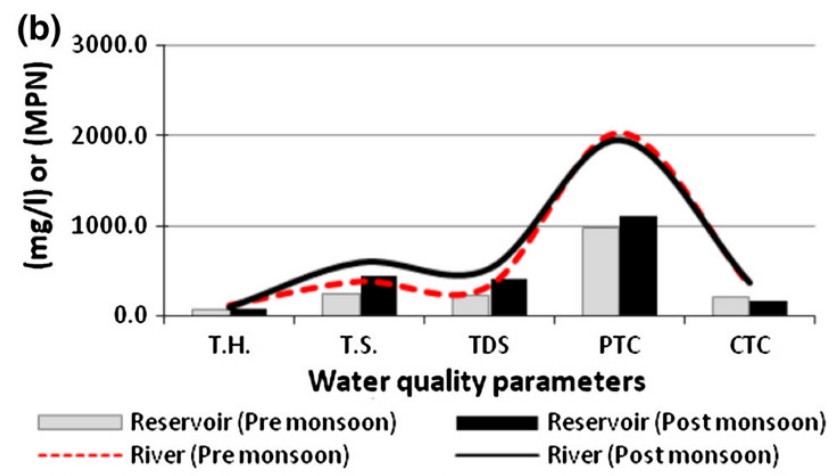

Note: TH, TS, TDS in $\mathrm{mg} / \mathrm{l}$ whereas PTC and CTC in MPN

(d)

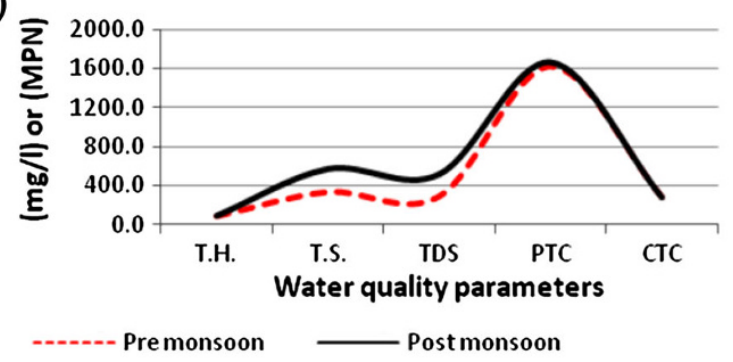

Note: TH, TS, TDS in mg/l whereas PTC and CTC in MPN

Fig. 5 Average water quality status at all observation locations in $\mathbf{a}, \mathbf{b}$ reservoir and river water and $\mathbf{c}, \mathbf{d}$ in RUA (cumulative of all surface water) during 2007-2010

Fig. 6 Percent change in water quality parameters during 2007-2010 in RUA

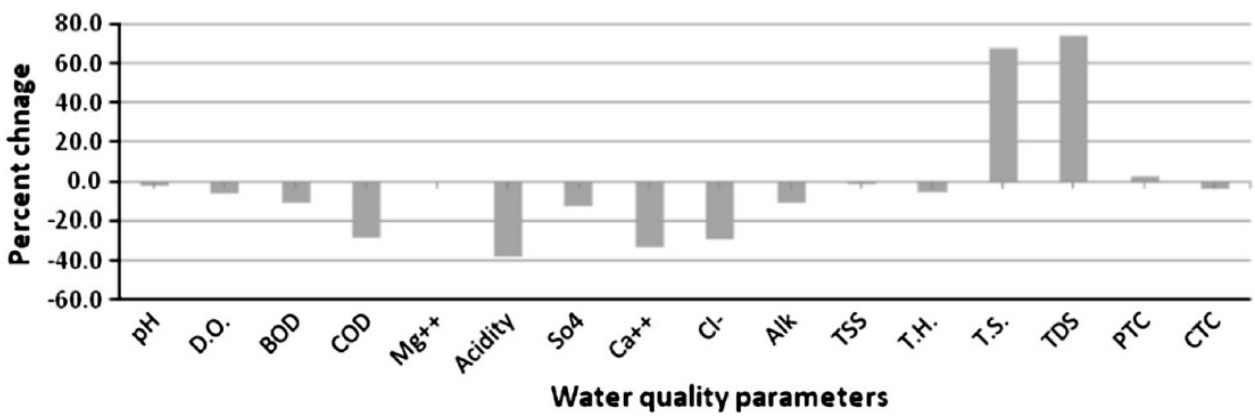

more in Swarnrekha river as compared to Jumar river (Fig. 7). The higher percentage of built-up area within the Swarnrekha catchment $(21.4 \%)$ compared to Jumar catchment $(8.9 \%)$ concludes the major cause of contamination as the presence of various industries (at HEC and Tantisilwai) as well as more discharge of municipal/ household wastes within catchment of Swarnrekha river (FAO 1995).

The surface water quality of the entire stretch of Swarnrekha river from Hatia reservoir to Tantisilwai signifies that river water was more contaminated as it moves away from its source (Fig. 8). The majority of pollutants were observed in maximum quantity in Swarnrekha river at Tantisilwai during pre as well as postmonsoon periods compared to its upstream locations at
Hatia and Namkum. This may be attributed to higher percentage of built-up land $(21.4 \%)$ compared to Namkum $(19.4 \%)$ and Hatia $(11.6 \%)$ as well as discharge of industrial effluents at Tantisilwai (Fig. 8a-d; Table 4). Majority of contaminants were found less in Jumar river followed by Swarnrekha river at Hatia and Namkum (Table 3).

The concentration of majority of chemical contaminants was decreased and bacteriological contaminants were increased in Swarnrekha and Jumar river during postmonsoon period in comparison to pre-monsoon periods (Fig. 8a-d). The concentration of TS, TDS, and CTC was increased in river water away from its source due to increase in catchment area, whereas PTC was reduced during post-monsoon periods. 


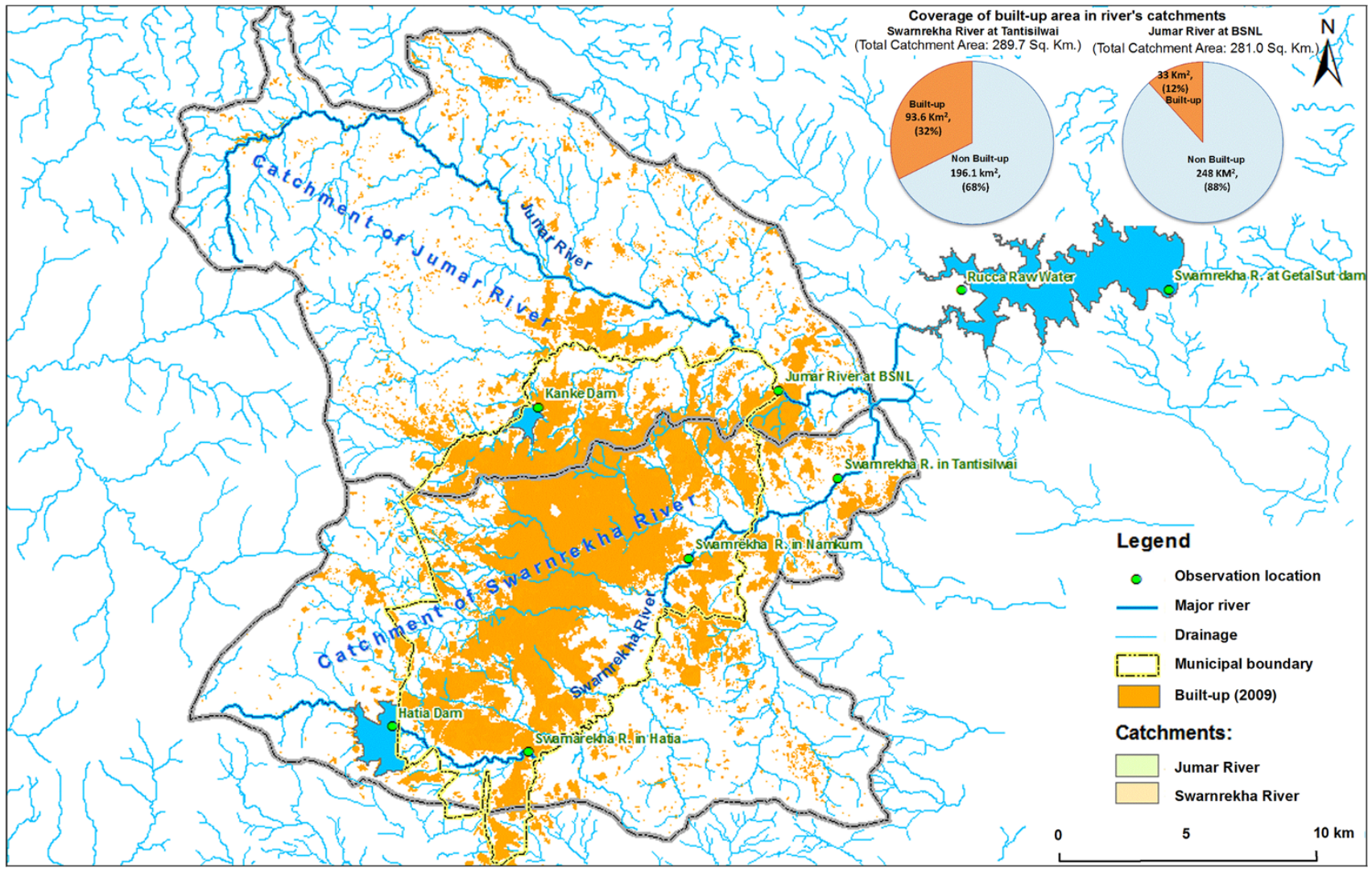

Fig. 7 Built-up land within the catchment of Jumar river and Swarnrekha river

Table 4 Statistics of built-up land within river catchments

\begin{tabular}{lllll}
\hline Catchment & $\begin{array}{l}\text { Catchment } \\
\text { area }\left(\mathrm{km}^{2}\right)\end{array}$ & $\begin{array}{l}\text { Built-up } \\
\text { land } \\
\left(\mathrm{km}^{2}\right)\end{array}$ & $\begin{array}{l}\text { Built-up } \\
\text { area }(\%)\end{array}$ & $\begin{array}{l}\text { Distance from } \\
\text { source }(\mathrm{km})\end{array}$ \\
\hline $\begin{array}{l}\text { Swarnrekha } \\
\text { river at Hatia }\end{array}$ & 66.6 & 7.7 & 11.6 & 16.1 \\
$\begin{array}{l}\text { Swarnrekha } \\
\text { river at } \\
\text { Namkum }\end{array}$ & 198.1 & 38.4 & 19.4 & 31.3 \\
$\begin{array}{l}\text { Swarnrekha iver } \\
\text { at Tantisilwai }\end{array}$ & 289.7 & 62.0 & 21.4 & 39.8 \\
$\begin{array}{l}\text { Jumar river at } \\
\text { BSNL }\end{array}$ & 281.0 & 25.1 & 8.9 & 38.3 \\
\hline
\end{tabular}

Comparative assessment of reservoir water quality

The reservoir water was found comparatively less polluted and was primarily affected by bacteriological contaminations due to inflow of biological pathogens derived from their catchment areas. The surface water spread area of the reservoir, topographical location within its watershed, urban area extent and land use in the catchment area exert prime control on the concentration of various pollutants. Getalsut reservoir exhibited the least chemical contamination (although affected by significant contamination of
PTC), lies in the lower parts of the catchment, and have larger water spread area than the Kanke reservoir, which is located in the upper parts of the catchment.

The average concentration of major water pollutants (i.e., BOD, TSS, TDS, PTC and CTC) was correlated with water spread area of reservoirs (Fig. 9a-d). It revealed that water spread area in reservoirs exhibits positive correlation with TDS concentration $\left(R^{2}=0.67\right)$ and negative correlations with PTC $\left(R^{2}=0.99\right)$, BOD $\left(R^{2}=0.21\right)$, and TSS $\left(R^{2}=0.08\right)$. This signifies that the amount of urban impervious surface (built-up) influences the non-point sources of pollution and water quality by directly affecting the amount of runoff to the water bodies (Dougherty et al. 2004).

Looking into the importance of Kanke and Hatia reservoir as a source of water supply to majority of localities in RUA and their comparable water spread area, a comparative evaluation of their water quality parameters with reference to land use/land cover in their catchment area was done. Higher concentration of majority of contaminants was observed in Kanke reservoir compared to Hatia reservoir during pre as well as post monsoon periods (Fig. 10a-d). This may be attributed to high coverage area of built-up land in Kanke reservoir catchment $(29.1 \%$ ) compared to Hatia reservoir catchment $(2.5 \%)$ as well as 
(a)

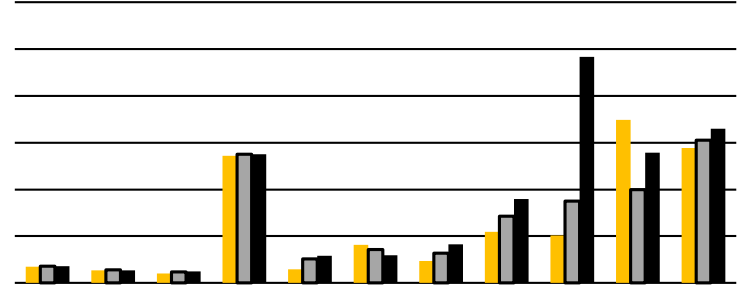

Water quality parameters

Swarnarekha R. in Hatia

$\square$ Swarnrekha R. in Namkum

(c)

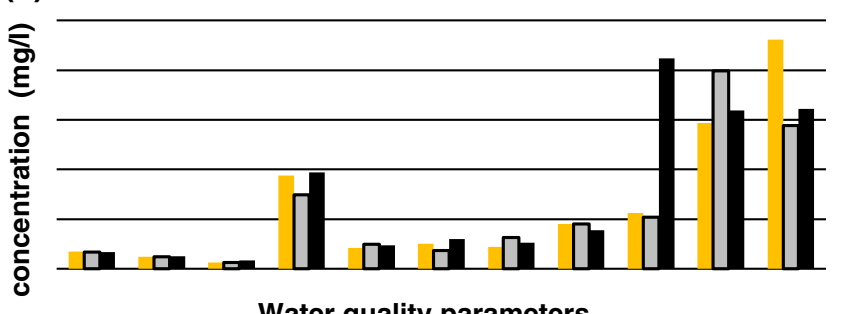

Water quality parameters

Swarnarekha R. in Hatia (b)

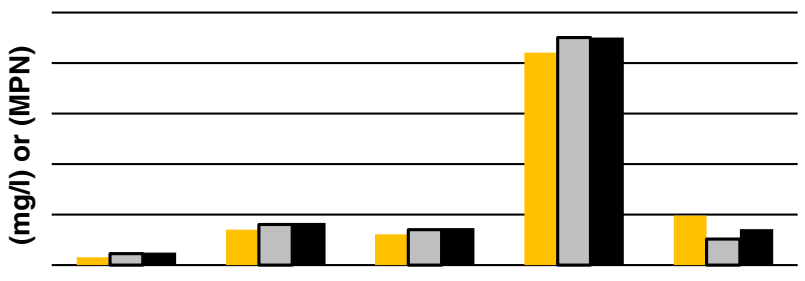

Water quality parameters

Swarnarekha R. in Hatia

$\square$ Swarnrekha R. in Namkum

Note: TH, TS, TDS in $\mathrm{mg} / \mathrm{l}$ whereas PTC and CTC in MPN

(d)

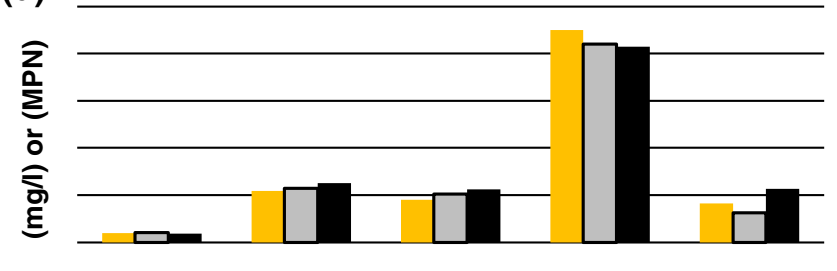

Water quality parameters

Swarnarekha R. in Hatia

$\square$ Swarnrekha R. in Namkum

Note: TH, TS, TDS in $\mathrm{mg} / \mathrm{l}$ whereas PTC and CTC

Fig. 8 Concentration of surface water pollutants during pre $(\mathbf{a}, \mathbf{b})$ and post $(\mathbf{c}, \mathbf{d})$ monsoon periods in downstream of Swarnrekha river

(a)

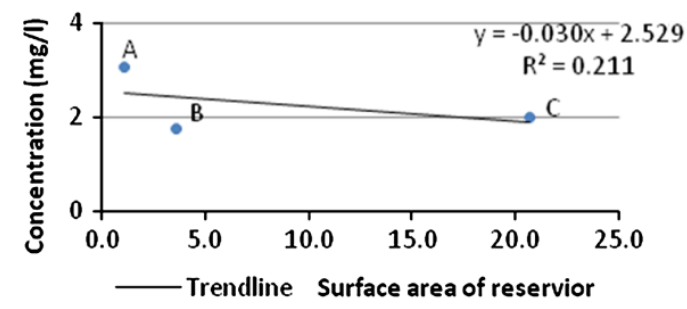

$A=$ Gonda reservior, $B=$ Hatia reservior, $C=$ Getalsut

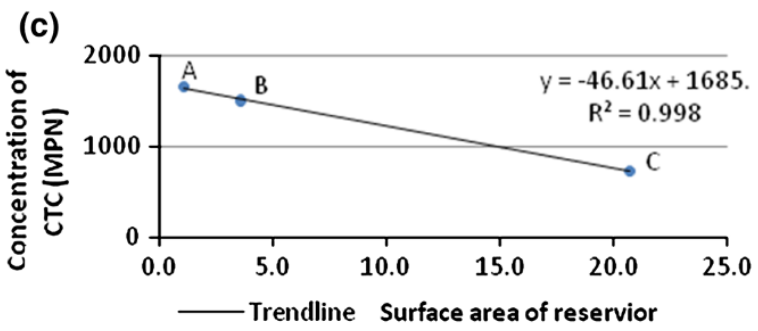

$\mathrm{A}=$ Gonda reservior, $\mathrm{B}=$ Hatia reservior, $\mathrm{C}=$ Getalsut (b)

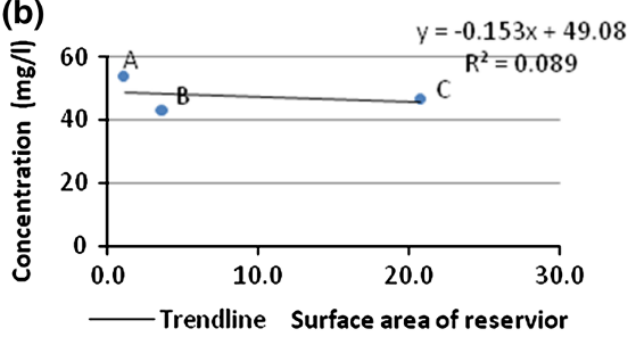

$A=$ Gonda reservior,$B=$ Hatia reservior,$C=$ Getalsut

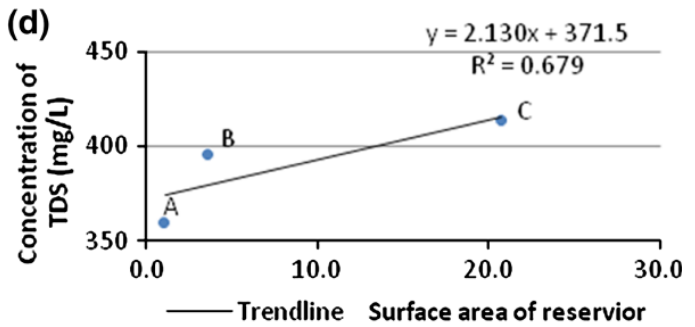

$\mathrm{A}=\mathrm{Gonda}$ reservior, $\mathrm{B}=\mathrm{H}$ atia reservior, $\mathrm{C}=\mathrm{Getalsut}$

Fig. 9 Correlation between reservoir area vs. a BOD concentration, b TSS, c PTC and, d TDS during 2007-2010 


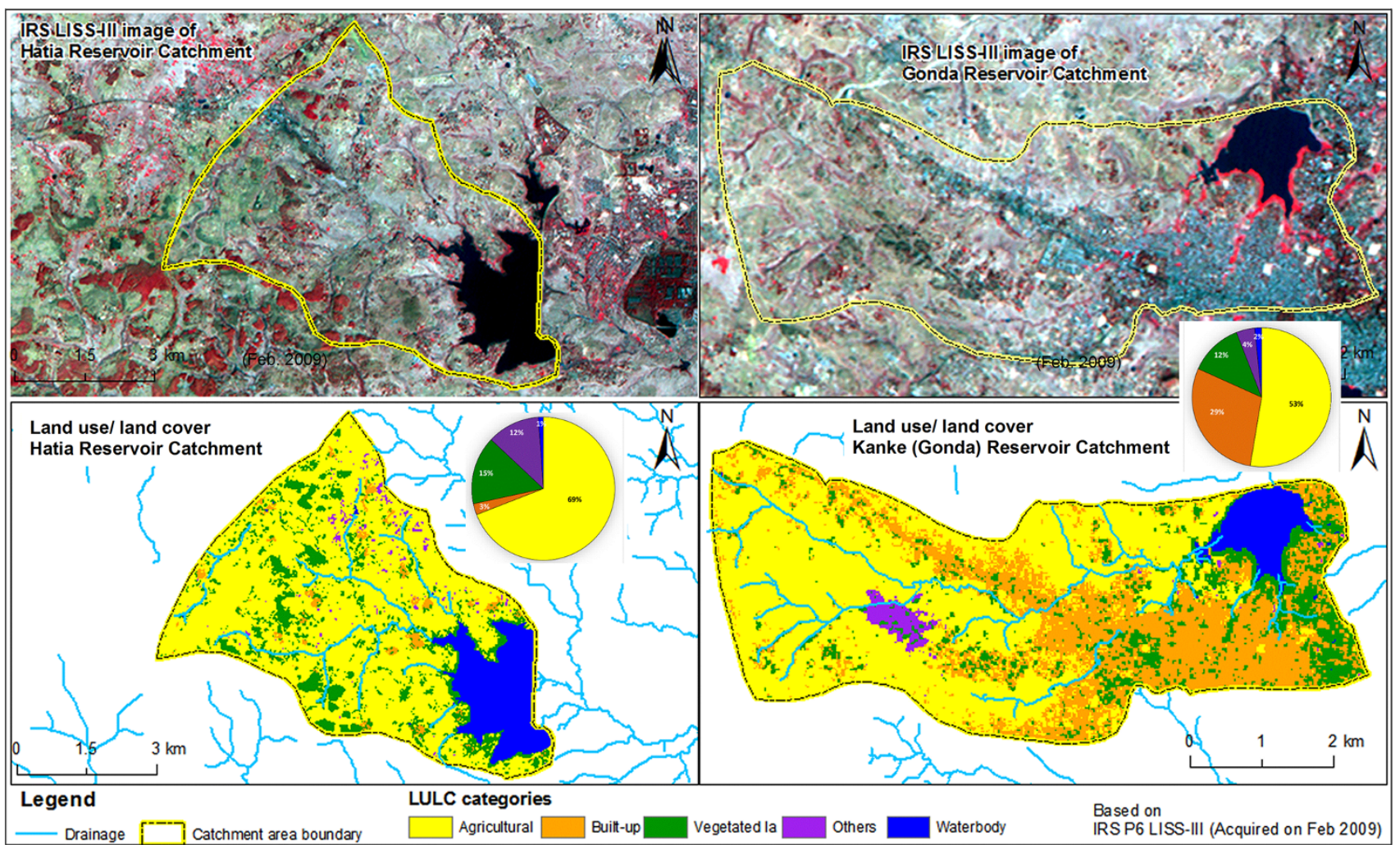

Fig. 10 Land use/land cover of the catchments of Hatia reservoir and Kanke reservoir

more water spread area in Hatia reservoir $\left(3.6 \mathrm{~km}^{2}\right)$ than Kanke reservoir $\left(1.1 \mathrm{~km}^{2}\right)$ (Figs. $\left.4 \mathrm{a}-\mathrm{d}, 10\right)$.

Built-up encroachment over drainage channels

Urban encroachment upon agricultural and forest lands often leads to environmental degradation and a loss of natural productivity (Kasimu and Tateishi 2008). The impact of urban expansion is experienced not only in fringe area but rather within urban core area. In RUA, the vacant land, open spaces, agricultural land and even river courses were the major locations, where built-up development had taken place due to increasing population pressure. The urban expansion in RUA over a period of 35 years for 1975-2005 involved 177.7 times increase in urban area primarily at the expense of agricultural land. Due to significant rise in land prices and commodity, people were settled down in low lying area ( $>600 \mathrm{~m}$ elevation) and within the vicinity of seasonal river courses which is considered as vulnerable location for human settlement due to seasonal flooding (Pandey et al. 2013).

It was observed that the river/drainage channels were primarily encroached by build-up land and few of the drainage channels were extinct due to urban activities over the last few decades. To ascertain the fact, a visual comparison was made between drainage network apparent in the topographical maps (published in 1972) and WorldView-II satellite imagery (acquired in 2010) followed by field verification. This clearly indicated that drainage channels were encroached upon by built-up land (Fig. 11a-d) and nearly extinct (Fig. 11e-1) at six locations. The paleochannels of extinct drainage channels are characterized by linear pattern of waterlogged lands with development of hydrophytes at different places. The standard FCC (BGR as 328) generated from WorldView-II satellite image clearly exhibits that these areas are smooth in texture and red in color. The built-up land development in the vicinity of the drainage channels within the urban area causes increase in channel runoff. The over exploitation of groundwater coupled with reduced rainfall pattern in recent past resulted in critical declining condition of groundwater in many parts of RUA. Therefore, encroachment upon the drainage channels may also lead to degradation of water quality due to insufficient water availability for dilution in surface as well as ground water.

In the present study, the increasing built-up expansion was examined in the vicinity of Swarnrekha and Jumar rivers as well as their tributaries draining through the RUA and surrounding regions using very high resolution WorldView-II satellite data of 2010. This indicated that the Swarnrekha river and its tributaries were largely encroached by built-up land $\left(0.70 \mathrm{~km}^{2}\right)$ from adjacent urban area than Jumar river and tributaries $\left(0.21 \mathrm{~km}^{2}\right)$ within the buffer zone of $50 \mathrm{~m}$ (Fig. 12). The built-up encroachment 

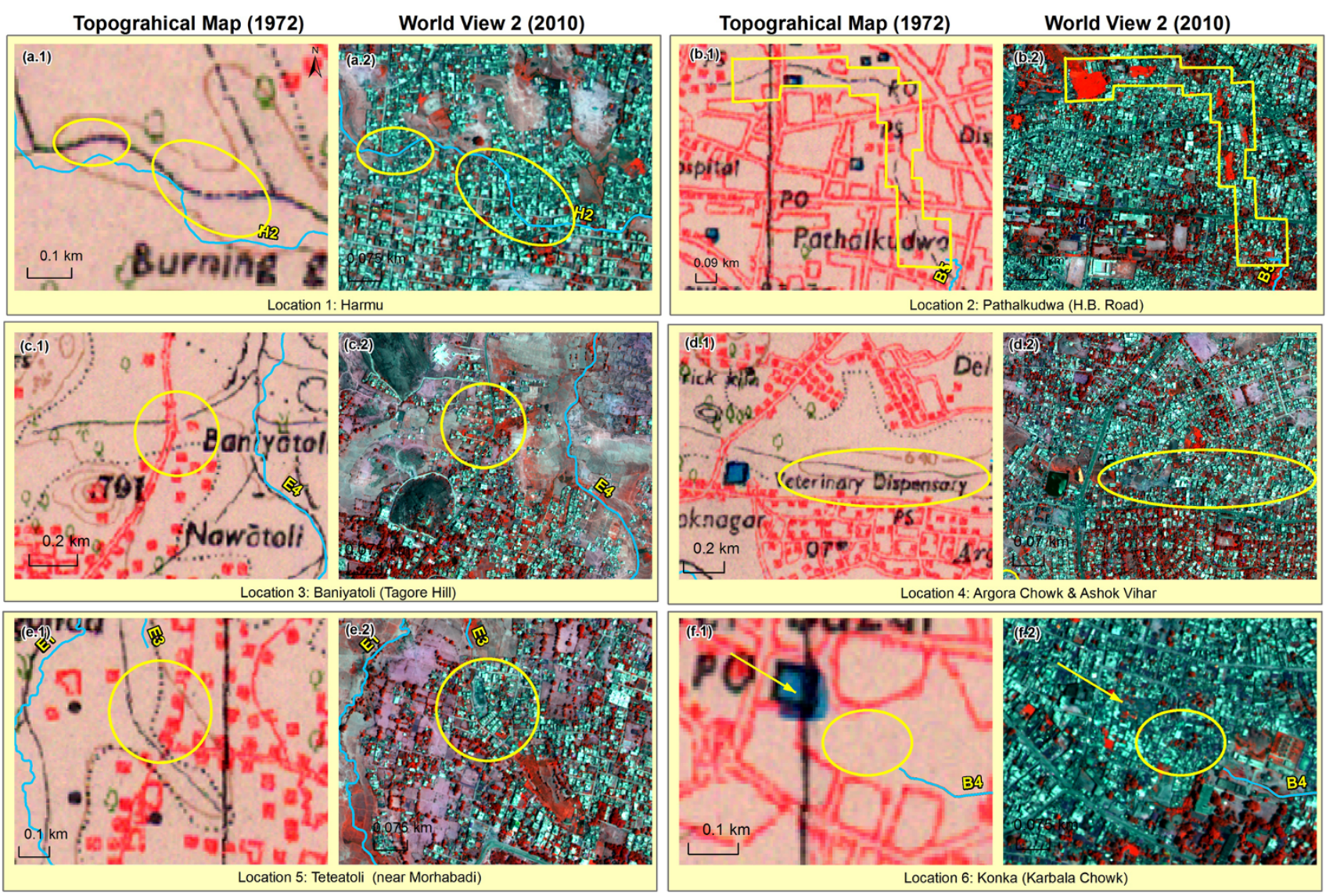

Fig. 11 Locations of major built-up encroachment over drainage in RUA (Topographical map 1972 and WorldView-II 2010)

Fig. 12 Built-up spread within the buffer zones (within 25 and $25-50 \mathrm{~m}$ ) along the drainage channels in RUA overlaid on high resolution WorldView-II satellite data (2010)

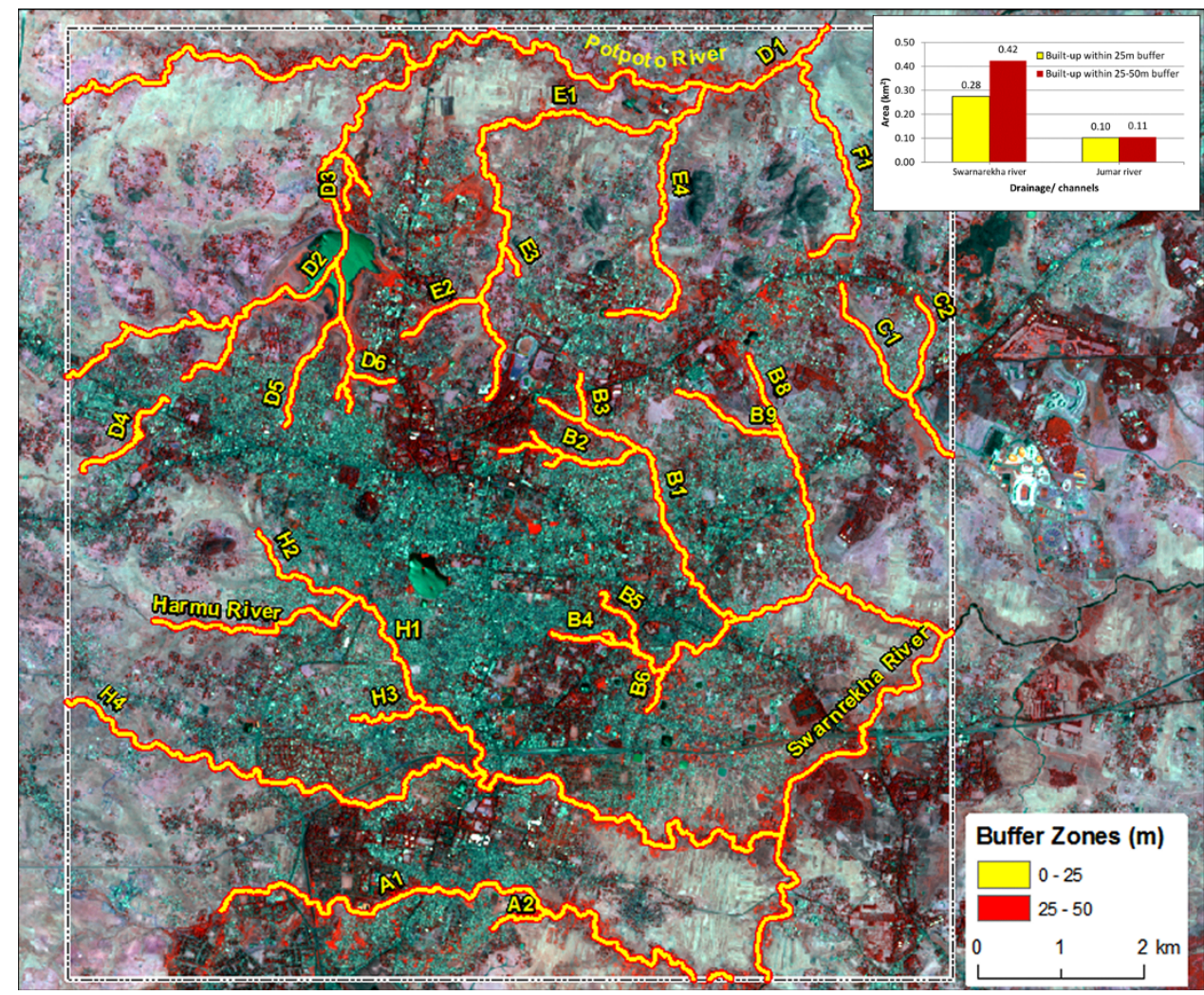




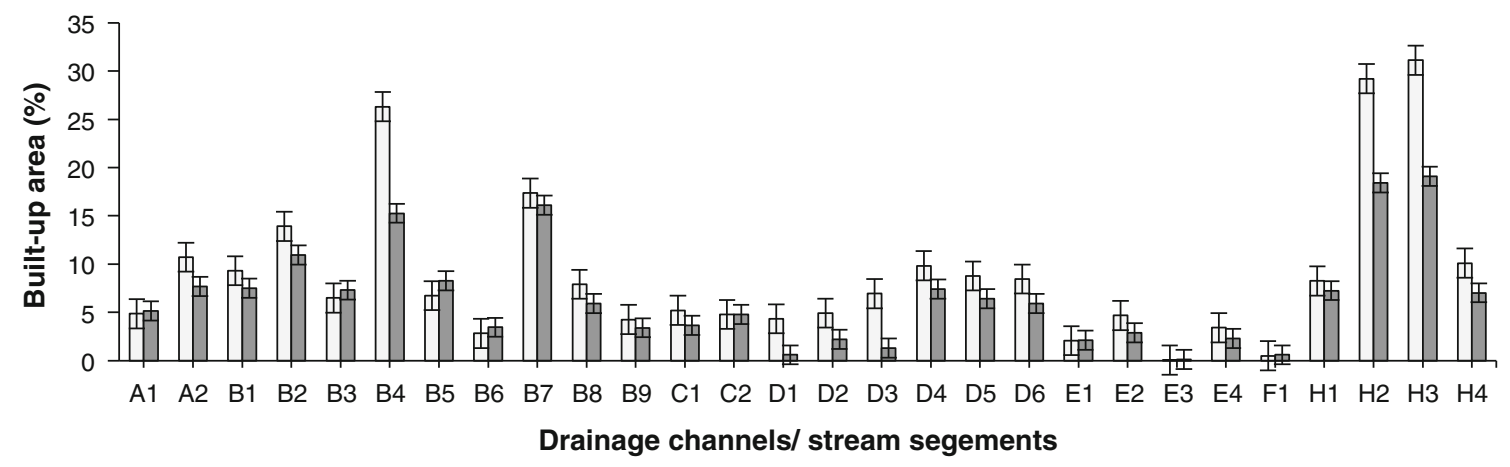

Fig. 13 Percentage of built-up land within buffer of drainage channels/stream segments in RUA in 2010

in Swarnrekha river and its tributaries were observed relatively much higher within the buffer zones of $25 \mathrm{~m}$ $(10.1 \%)$ and $25-50 \mathrm{~m}(7.8 \%)$ compared to Jumar river and its tributaries (4.5 and $2.4 \%$, respectively).

Built-up encroachment within the buffer zones of $0-25$ and $25-50 \mathrm{~m}$ of river channels were further analyzed with reference to each drainage channel segment which exhibited higher encroachment in the tributary of Harmu river (i.e., H1) by built-up land $\left(0.048 \mathrm{~km}^{2}\right.$ within $25 \mathrm{~m}$ buffer and $0.085 \mathrm{~km}^{2}$ within 25-50 m buffer) compared to B4, B1, H4, H2, D1 and A1 stream segments (Figs. 12, 13). The percentage of built-up land within the buffer zones of 25 and $25-50 \mathrm{~m}$ comprises about 25 and $15 \%$ area, respectively. On the contrary, the stream segments of Jumar river comprised only $10 \%$ area of built-up land within the $50 \mathrm{~m}$ proximity. It was found that due to anthropogenic activities especially built-up development and development of roads, the natural flow of drainage system in and around RUA disturbed the surrounding area and lead to water logging at large number of location (Argorachowk, HEC Karialai School, Bariatu) causing deterioration in urban environment (Fig. 11).

Due to increasing demand for groundwater vis-a-vis depleting groundwater levels in the region, land developers are locating their housing societies in the vicinity of seasonal rivers or abandoned channels, where groundwater remains at shallow level with quality groundwater. Apart from vulnerability of such areas to seasonal flooding or waterlogging, the urban expansion in the vicinity of river banks reduces the groundwater recharge and increases the runoff with concomitant deterioration of groundwater and/ or surface water quality.

\section{Conclusion}

The high rate of built-up growth (39.0\%) as well as population growth (32.6\%) increased the pressure over the existing water resources due to formation of Ranchi as state capital. The surface water quality monitoring in the urban regime indicated increasing tendency of concentration of few organic and biological contaminants viz., BOD, TSS, TDS, PTC and CTC. This could be attributed to increasing discharge of municipal wastewater mostly in untreated form from industries and households into the Subarnarekha river and its tributaries. Majority of rivers were not contaminated in its entire lengths but polluted in specific segments, indicating wastewater discharges from certain urban areas and industries.

The study identified reservoir as comparatively less polluted than the river due to higher availability of water for dilution of pollutants in the reservoir. It can be concluded that the surface water of RUA is not suitable for drinking and needs treatments to minimize the contamination caused by higher concentration of PTC, BOD and TDS. The level of contamination is directly related to the land use (industrial/residential) and location of built-up (rural/urban) land in the catchment region of reservoirs and rivers. The present study identified four highly contaminated river stretches. The built-up spread in the proximity of drainage channels represented high encroachment in the tributary streams of Swarnrekha in comparison to Jumar river. Harmu river and its tributaries were highly encroached by built-up land $\left(0.31 \mathrm{~km}^{2}\right)$ within RUA leading to the formation of large number of waterlogged areas.

The study indicates towards adoption and implementation of suitable safe water development strategies to arrest further decline of the water quality in the urban area. Therefore various techniques viz., effective implementation of Total Sanitation Campaign (TSC) to develop household toilet in urban as well as rural areas, proper disposal of sewerage, proper solid and liquid water treatment (municipal and industrial) may be adopted. Reuse of waste water, preservation of open spaces (pervious) within the urban area, adoption of urban plantation activities, etc., may also be adopted to limit the deteriorating water quality of urban area.

Acknowledgments Authors are thankful to the anonymous reviewers for their comments and suggestions for improving the quality of the manuscript. Authors express gratitude to Jharkhand State Pollution Control Board, Govt. of Jharkhand, India and Digital Globe Inc., USA for providing data (surface water quality data and WorldView-II satellite data, respectively) for the study. 
Open Access This article is distributed under the terms of the Creative Commons Attribution License which permits any use, distribution, and reproduction in any medium, provided the original author(s) and the source are credited.

\section{References}

Arnold CL, Gibbons CJ (1996) Impervious surface coverage: the emergence of a key environmental indicator. J Am Plan Assoc 62(2):243-258

Asante KA, Quarcoopome T, Amevenku FYK (2008) Water quality of the Weija reservoir after 28 years of impoundment West African. J Appl Ecol 13(1):125-131

Atasoy M, Palmquist RB, Phaneuf DJ (2006) Estimating the effects of urban residential development on water quality using microdata. J Environ Manag 79:399-408

Department for International Development (DFID) (1999) Assessment of environmental water quality standard. Final report. Water Engineering and Development Centre, Loughborough University, UK

Dougherty M, Dymond RL, Goetz SJ, Jantz CA, Goulet N (2004) Evaluation of impervious surface estimates in a rapidly urbanizing watershed. Photogramm Eng Remote Sens 70:1275-1284

FAO (1995) Fisheries technical paper, Version: T345, ISBN: 925103673X, ISSN: 0429-9345. http://www.fao.org/docrep/ 003/v5930e/V5930E15.htm

Held I, Wolf L, Eiswirth M, Hotzl H, (2007) Impacts of sewer leakages on groundwater. In: Tellam JH, Rivett MO, Israfilov RG, Herringshaw LG (ed) Urban groundwater management and sustainability, NATO book series, 74, pp 189-204

Jaiswal RK, Mukherjee S, Krishnamurthy J, Saxena R (2003) Role of remote sensing and GIS techniques for generation of groundwater prospect zones towards rural development: an approach. Int J Remote Sens 24:993-1008

Jat MK, Khare D, Garg PK (2009) Urbanization and its impact on groundwater: a remote sensing and GIS-based assessment approach. Environmentalist 29:17-32
Kasimu A, Tateishi R (2008) Global urban mapping using population density, MODIS and DMSP data with the reference of LANDSAT images. Proc Int Arch Photogramm Remote Sens Spat Inf Sci 37:1523-1528

Kumar A, Pandey AC, Hoda N, Jeyaseelan AT (2011a) Evaluating the long-term urban expansion of RUA, India using geospatial technology. J Indian Soc Remote Sens 39(2):213-224

Kumar A, Pandey AC, Hoda N, Jeyaseelan AT (2011b) Evaluation of urban sprawl pattern in tribal dominated cities of Jharkhand State, India. Int J Remote Sens 32(22):7651-7675

Kumar A, Pandey AC, Jeyaseelan AT (2012) Built-up and vegetation extraction and density mapping using worldview-II. Geocarto Int 27(7):557-568

Mapani BS (2005) Groundwater and urbanization, risk and mitigation: the case for the city of Windhoek, Namibia. Phys Chem Earth 30:706-711

Nezband M, Jurgens C (2010) Urban and suburban areas as a research topic for remote sensing. In: Rashed T, Jurgens C (eds) Remote sensing of urban and suburban areas. Springer, London

Pandey AC, Kumar A, Jeyaseelan AT (2013) Urban built-up area assessment of Ranchi township using Cartosat-I stereopairs satellite images. J Indian Soc Remote Sens 41(1):141-155

Shaikh AM, Mandre PN (2009) Seasonal study of physico-chemical parameters of drinking water in Khed (Lote) industrial area. Shodh Samiksha aur Mulyankan 2(7):169-171

Singh SP, Pathak D, Singh R (2002) Hydrobiological studies of two ponds of Satna (M. P.), India. Ecol Environ Conserv 8(3):289-292

Sunday E (2003) Total maximum daily load for DO for the grand, north branch grand and portage rivers, Jackson County, Michigan

United Nations Population Division (UNPD) (2010) World urbanization prospects: the 2009 revision population database. (http:// esa.un.org/wup/source/country.aspx)

Wilson C, Weng Q (2010) Assessing surface water quality and its relation with urban land cover changes in the lake calumet area, Greater Chicago. Environ Manag 45(5):1096-1111 